\title{
Molecular detection of Schistosoma japonicum in infected snails and mouse faeces using a real-time PCR assay with FRET hybridisation probes
}

\author{
Tongjit Thanchomnang ${ }^{1,2}$, Pewpan Intapan ${ }^{1,3}$, Pusadee Sri-Aroon ${ }^{4}$, Viraphong Lulitanond ${ }^{1,5}$, \\ Penchome Janwan ${ }^{1,3}$, Oranuch Sanpool ${ }^{1,3}$, Wanchai Maleewong ${ }^{1,3} /+$ \begin{abstract}
Faculty of Medicine, Khon Kaen University, 40002 Khon Kaen, Thailand 'Faculty of Medicine, Mahasarakham University, Mahasarakham, Thailand ${ }^{4}$ Applied Malacology Center, Department of Social and Environmental Medicine, Faculty of Tropical Medicine, Mahidol University, Bangkok, Thailand
\end{abstract} \\ ${ }^{1}$ Research and Diagnostic Center for Emerging Infectious Diseases ${ }^{3}$ Department of Parasitology ${ }^{5}$ Department of Microbiology,
}

A real-time polymerase chain reaction (PCR) assay with fluorescence resonance energy transfer (FRET) hybridisation probes combined with melting curve analysis was developed to detect Schistosoma japonicum in experimentally infected snails and in faecal samples of infected mice. This procedure is based on melting curve analysis of a hybrid between an amplicon from the $\mathrm{S}$. japonicum internal transcribed spacer region 2 sequence, which is a 192-bp S. japonicum-specific sequence, and fluorophore-labelled specific probes. Real-time FRET PCR could detect as little as a single cercaria artificially introduced into a pool of 10 non-infected snails and a single egg inoculated in $100 \mathrm{mg}$ of non-infected mouse faeces. All S. japonicum-infected snails and all faecal samples from infected mice were positive. Non-infected snails, non-infected mouse faeces and genomic DNA from other parasites were negative. This assay is rapid and has potential for epidemiological $\mathrm{S}$. japonicum surveys in snails, intermediate hosts and faecal samples of final hosts.

Key words: Schistosoma japonicum - real-time fluorescence resonance energy transfer PCR - DNA - snails - mice

Schistosoma japonicum is an important trematode that causes human schistosomiasis in Asia, including the People's Republic of China, the Philippines and some areas in Indonesia (Zhou et al. 2010). The re-emergence and active transmission of $S$. japonicum in endemic areas, with a recent infection of approximately 700,000 people, have been reported (Zhou et al. 2007). The S. japonicum life cycle involves a snail intermediate host and a definitive host. Adult schistosomes lay eggs in the mesenteric vein capillaries, which drain the small intestine in the definitive host. The eggs embedded in the intestinal submucosa and mucosa break into the lumen of the bowel and appear in the faeces. In water, the eggs give rise to miracidia, the infective stage of the snail intermediate host. Miracidia penetrate into and migrate through snail tissues to develop into sporocysts, which give rise to cercariae. Humans become infected by coming in contact with water contaminated with cercariae, which actively penetrate into the skin. Parasite transmission requires three factors: surface water contamination with faecal excreta, the presence of specific fresh water snails as the first intermediate host and human water contact

Financial support: NSTDA (Discovery Based Development Grant), Higher Education Research Promotion, National Research University Project of Thailand, OHEC, Thailand

+ Corresponding author: wanch_ma@kku.ac.th

Received 15 March 2011

Accepted 6 September 2011
(Gryseels et al. 2006). In definitive mammalian hosts, $S$. japonicum cause feverish syndrome, intestinal diseases and hepatosplenic inflammation in the acute stage of the infection and liver fibrosis in the chronic stage (Gryseels et al. 2006). Human infection has been associated with anaemia (King et al. 2005), hepatosplenomegaly and liver fibrosis, as well as liver and colon cancers (Qiu et al. 2005). Egg detection by stool examination remains the standard method to diagnosis human schistosomiasis japonica. However, it is difficult to differentiate between S. japonicum and Schistosoma mekongi eggs by stool examination; it is not feasible during the prepatent period and it is not sensitive enough to detect mild infections (Doenhoff et al. 2004). Parasite-specific antibody detection by enzyme-linked immunosorbent assay has a high sensitivity and is useful for mass screening, but it has the limitation of a relatively low specificity due to cross-reactivity, and it does not always correlate with an active infection (Doenhoff et al. 2004). The detection of parasite DNA in host-derived material is direct evidence of an actual infection, which is why molecularbased approaches to detect $S$. japonicum DNA, such as conventional polymerase chain reaction (c-PCR) and loop-mediated isothermal amplification, have been developed (Xia et al. 2009, Kato-Hayashi et al. 2010, Xu et al. 2010). Recently, a SYBR ${ }^{\circledR}$ green-based real-time PCR (Lier et al. 2006, 2008), a minor groove-binding probebased real-time PCR (Lier et al. 2009), and a TaqMan probe-based real-time PCR (Hung \& Remais 2008) were published as sensitive and fast methods that could quantify specific $S$. japonicum DNA in biological samples and in environmental water. In contrast with previous 
reports, S. japonicum DNA detection based on the fast, specific and reliable real-time fluorescence resonance energy transfer (FRET) PCR combined with melting curve analysis is promising for detecting an array of parasites from biological specimens (Intapan et al. 2008a, b, 2009a, b). Here, we report the possible applicability of this real-time FRET PCR combined with melting curve analysis to detect $S$. japonicum larvae in snails and eggs in faecal samples of infected mice.

\section{SUBJECTS, MATERIALS AND METHODS}

Parasite and DNA materials - S. japonicum (Japanese Yamanashi strain) - Experimentally infected Oncomelania nosophora snails and mice, as well as $S$. japonicum adults and cercariae, were obtained from the Applied Malacology Center, Department of Social and Environmental Medicine, Faculty of Tropical Medicine, Mahidol University, Thailand. All animal experiments were handled according to the Guidelines for Animal Experimentation of the National Research Council of Thailand.

$S$. japonicum (Philippine strain) adults and $S$. japonicum experimentally infected Oncomelania quadrasi snails, as well as $S$. mekongi (Loatian strain) adults and $S$. mekongi infected mice, were also provided obtained from the Faculty of Tropical Medicine, Mahidol University. To evaluate the analytical specificity of the real-time FRET PCR, other parasite DNA was extracted from the adult worms of Opisthorchis viverrini, Haplorchis taichui, Centrocestus spp, Echinostoma malayanum, Fasciola gigantica, Paragonimus heterotremus and Stellantchasmus spp, as well as from metacercariae of Haplorchoides spp, cercariae of animal schistosomes, healthy human faeces, human leukocytes and human faeces infected with Strongyloides stercoralis, Taenia spp, Echinostoma spp and intestinal lecithodendriid flukes. The DNA samples were kept in a DNA bank at $-70^{\circ} \mathrm{C}$ in the Department of Parasitology, Faculty of Medicine, Khon Kaen University until use.

Specimen preparation for real-time FRET PCR DNA samples were extracted from all non-infected $(\mathrm{n}=$ $30)$ and experimentally infected $(n=30)$ snails, including their shells, and from snail tissue samples artificially inoculated with $S$. japonicum cercariae. Each specimen was homogenised with disposable polypropylene pestles (Bellco Glass Inc Vineland, NJ, USA) and extracted using the Nucleospin Tissue kit (Macherey-Nagel GmbH \& Co, Duren, Germany). For DNA extraction from mouse faeces, $100 \mathrm{mg}$ of each $S$. japonicum-infected mouse faeces, non-infected mouse faeces and non-infected mouse faeces artificially inoculated with $S$. japonicum eggs were thoroughly mixed with $200 \mu \mathrm{L}$ of normal saline solution $(0.85 \% \mathrm{NaCl}$ in distilled water) and centrifuged at $8,000 \mathrm{~g}$ for $5 \mathrm{~min}$. The supernatant was then discarded and the faecal pellet was frozen at $-20^{\circ} \mathrm{C}$ for $30 \mathrm{~min}$. The frozen pellets were homogenised with disposable polypropylene pestles (Bellco Glass Inc) and extracted using the QIAamp ${ }^{\circledR}$ DNA stool mini kit (Qiagen, Hilden, Germany). The number of $S$. japonicum eggs in the faeces of infected mice $(n=10)$ was presented as eggs per gram (EPG) of faeces (ranging from 100-1,100 EPG; geomet- ric mean $=302 \mathrm{EPG}$ ). The DNA was eluted in $100 \mu \mathrm{L}$ of distilled water, $5 \mu \mathrm{L}$ of which was used for the real-time $\mathrm{PCR}$ reaction.

Limit of detection - To determine the limit of detection of the real-time FRET PCR, tissues from non-infected snails were separately ground. Next, individual aliquots of one, five and 10 non-infected snail samples were separately inoculated with one, five, 10 and $30 \mathrm{~S}$. japonicum cercariae. Similarly, $100 \mathrm{mg}$ faecal aliquots of non-infected mice were separately inoculated with a serial dilution of one, two, four and eight $S$. japonicum eggs. These samples were also used for genomic DNA extraction as described above. The resultant DNA samples were then used in the real-time FRET PCR.

To evaluate the analytical specificity of the method, genomic DNA from the $S$. mekongi, O. viverrini, Centrocestus spp, $H$. taichui, F. gigantica, E. malayanum, P. heterotremus, Haplorchoides spp, Stellantchasmus spp and animal schistosomes, as well as DNA extracted from human leukocytes, negative human faeces and human faeces infected with $S$. stercoralis, Taenia spp, intestinal lecithodendriid flukes and Echinostoma, were purified as mentioned above.

Real-time FRET PCR assay - The LightCycler PCR detection and analysis systems (LightCycler 2.0, Roche Applied Science, Mannheim, Germany) were used for amplification and quantification. The reactions were performed in glass capillaries. The specific primers SJ-F (5'-ATGTTTGATGCGCTCGTA-3') and SJ-R (5'AACTTAGCTTACGGTAGGTG-3') (Proligo, Singapore) were designed to bind to the $S$. japonicum internal transcribed spacer region 2 (ITS2) sequence (GenBank accession U22167) (Bowles et al. 1995). For amplification detection, the LightCycler FastStart DNA Master HybProbe Kit was used according to the protocol recommended by the manufacturer. Briefly, a pair of adjacent oligo probes were hybridised with the $S$. japonicum ITS2. One probe was labelled at the 5 ' end with the LightCycler Red 640 fluorophore (5' Red 640-GTCCGGTCTAGATAGCCAGATTAAGATGCTGCAG-Phosphate 3'; SJLC640 probe) and the other was labelled at the 3' end with a 530 fluorescein (5'CCGTCCGAATAATCCGACCACAGCC - Flou 530 3'; SJFL530 probe) (Tib Molbiol, Berlin, Germany). The probes and primers were designed by $\mathrm{LC}$ probe design software (Roche Applied Science). A schematic diagram of the hybridisation analysis of the primers and probes is shown in Fig. 1. When the probes hybridised to the same DNA strand internal to the PCR primers, the probes came in close proximity and produced a FRET (Intapan et al. 2009a). The PCR mixture contained $2 \mu \mathrm{L}$ LightCycler Faststart DNA Master HybProbe $(10 \times$ conc. $)$, $2 \mathrm{mM} \mathrm{MgCl}, 0.2 \mu \mathrm{M}$ SJ-F primer, $0.2 \mu \mathrm{M}$ SJ-R primer, $0.2 \mu \mathrm{M}$ SJLC640 probe and $0.2 \mu \mathrm{M}$ SJFL530 probe. The total reaction volume was $20 \mu \mathrm{L}$. The samples were run through 45 cycles of repeated denaturation $(10 \mathrm{~s}$ at $\left.95^{\circ} \mathrm{C}\right)$, annealing $\left(30 \mathrm{~s}\right.$ at $\left.55^{\circ} \mathrm{C}\right)$ and extension $(10 \mathrm{~s}$ at $72^{\circ} \mathrm{C}$ ). The temperature transition rate was $20^{\circ} \mathrm{C} / \mathrm{s}$. After amplification, a melting curve was produced by heating the product at $20^{\circ} \mathrm{C} / \mathrm{s}-95^{\circ} \mathrm{C}$, which was then cooled to 
$65^{\circ} \mathrm{C}$, incubated at $65^{\circ} \mathrm{C}$ for $3 \mathrm{~s}$ and then slowly heated at $0.1^{\circ} \mathrm{C} / \mathrm{s}-80^{\circ} \mathrm{C}$. The fluorescence intensity change was measured throughout the slow heating phase. To evaluate the analytical specificity of the oligonucleotide hybridisation FRET-based technique, DNA extracted from samples other than S. japonicum-infected snail and mouse faecal samples were separately analysed. Each run contained at least one negative control consisting of $5 \mu \mathrm{L}$ distilled water. For improved visualisation of the melting temperatures $(\mathrm{Tm})$, melting curves were derived as previously described (Thanchomnang et al. 2008). Melting curves were used to determine the specific PCR products, which were confirmed by conventional gel electrophoresis. The cycle number $(\mathrm{Cn})$ was presented as the number of PCR cycles needed for the amplicon fluorescence signal to exceed the detected threshold value.

S. japonicum-positive control plasmid - A positive control plasmid was constructed by cloning a PCR product of the $S$. japonicum ITS2 into the pGEM-T Easy vector (Promega, Madison, WI) according to the protocol of the manufacturer. The PCR products were obtained by c-PCR using the SJ-F and SJ-R primers. The plasmid was propagated in Escherichia coli, and the nucleotide sequence of the inserted gene was sequenced in both directions. The cloned ITS2 nucleotide sequence was identical to the $S$. japonicum genomic sequence (GenBank accession U22167).

Data analysis - The correlation between the worm loads and the Cn was analysed by the Pearson's correlation test.

\section{RESULTS}

Real-time PCR standardisation - The analytical sensitivity of the real-time FRET PCR was evaluated using $5 \mu \mathrm{L}$ of serial dilutions $\left(1.42 \times 10-1.42 \times 10^{8}\right.$ copies $)$ of $S$. japonicum positive control plasmid in distilled water. The limit of detection of the ITS2 gene target DNA sequence was $1.42 \times 10^{2}$ copies of positive control plasmid (Fig. 2A) or as little as $10^{-2} \mathrm{ng}$ S. japonicum genomic DNA (Fig. 2B) when considering 35 cycles as the cut-off detection limit. No fluorescence signal was obtained when purified DNA from the following was tested: non-infected $O$. nosophora

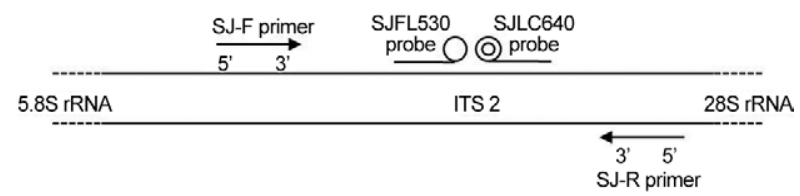

Fig. 1: schematic illustration of the polymerase chain reaction primers (SJ-F and SJ-R primers), anchor and detection probes hybridized with the Schistosoma japonicum internal transcribed spacer region 2 (ITS2) (GenBank accession U22167). The probe SJFL530 was labelled with 530 fluorescein at the $3^{\prime}$ end and served as anchor probe for the sensor SJLC640 probe. The sensor probe was labelled with LightCycler Red 640 fluorophore (LC red 640) at the 5' end. The left and right dashed line indicate the 5.8S ribosomal RNA gene (5.8S rRNA) and $28 \mathrm{~S}$ ribosomal RNA gene (28S rRNA), respectively, whereas the middle line indicates the ITS2. Single circle: 530 fluorescein; double circle: LC red 640. snails, non-infected mouse faeces, O. viverrini, Centrocestus spp, H. taichui, F. gigantica, E. malayanum, $P$. heterotremus, Haplorchoides spp, Stellantchasmus spp, animal schistosomes, S. mekongi and S. mekongi-infected mouse faeces, human leukocytes, negative human faeces and human faeces infected with $S$. stercoralis, Taenia spp, Echinostoma and intestinal lecithodendriid flukes.

With regards to the limit of detection, as little as a single egg could be detected in $100 \mathrm{mg}$ non-infected mouse faeces based on the 192-bp band in the ethidium bromidestained gel (Fig. 3A, Lane 2). DNA samples from each aliquot of one, five and 10 non-infected $O$. nosophora snail tissues artificially inoculated with one $S$. japonicum cercaria were amplified (Fig. 3B, Lanes 7-9).

Real-time FRET PCR for the detection of S. japonicum in infected O. nosophora snails and mice - A total of $30 \mathrm{~S}$. japonicum-infected, 30 non-infected $O$. nosophora snails,

A

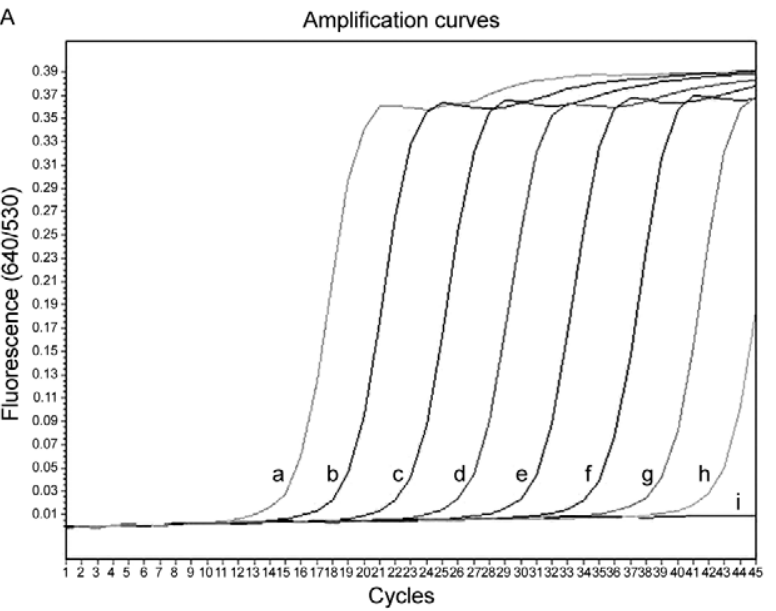

B

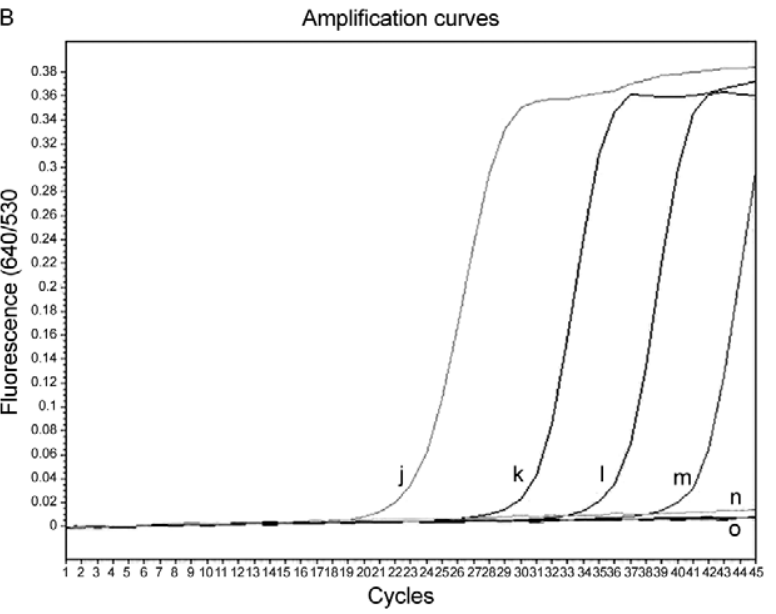

Fig. 2: amplification plot of fluorescence (y-axis) vs. cycle numbers (x-axis) shows the analytical sensitivity of the real-time polymerase chain reaction for detecting serial dilutions of Schistosoma japonicum plasmid DNA copies (A) and genomic DNA (B). a-h: 10-fold dilutions concentrations of $S$. japonicum plasmids from $1.42 \times 10^{8}-14.2$ copies per reaction; i, o: distilled water; $\mathrm{j}$-n: 10 -fold dilutions concentrations of $S$. japonicum genomic DNA from 1-1 $\times 10^{-4} \mathrm{ng}$. 
10 S. japonicum-infected and 10 non-infected mouse faecal samples were analysed separately. The melting curve analyses are shown in Fig. 4. When using S. japonicumspecific primers and probes, the mean \pm standard deviation (SD), range and the median of the Tm values of the $S$. japonicum-infected $O$. nosophora snails were $68.98 \pm$ $0.05,68.93-69.06$ and 68.99, respectively, and those of the S. japonicum-infected mouse faecal samples were 68.64 $\pm 0.29,68.12-69.00$ and 68.68 , respectively. A total of 30 $S$. japonicum-infected $O$. nosophora snails ( $\mathrm{Cn}$ range $=$ 9.61-15.07; mean $\pm \mathrm{SD}=10.97 \pm 2.33$; median $=9.84)$ and $10 \mathrm{~S}$. japonicum-infected mouse faecal samples $(\mathrm{Cn}$ range $=22.04-30.03$; mean $\pm \mathrm{SD}=25.41 \pm 2.5$; median $=$ 25.78) were positive by real-time FRET PCR with melting curve analysis, whereas all of the specific control DNAs were negative. However, no significant correlation between the $\mathrm{Cn}$ and the $S$. japonicum eggs intensity in the faecal samples were reported $(p>0.050)$ (data not shown). The positive and negative rates were $100 \%$. To ensure this procedure can detect $S$. japonicum DNA from different strains, DNA extracted from $S$. japonicum Philippine strain adults and from $O$. quadrasi snails experimentally infected with the S. japonicum Philippine strain were also examined by this method. All samples were positive and the nucleotide sequences of the amplified products were identical to that of the $S$. japonicum Japanese Yamanashi strain (data not shown).

The validity of the real-time FRET PCR method used in this study was verified by the presence of a prominent 192-bp product, which was amplified from the DNAs of the $S$. japonicum-infected $O$. nosophora snails, S. japonicum-infected mouse faeces, $S$. japonicum cercariae, $S$.

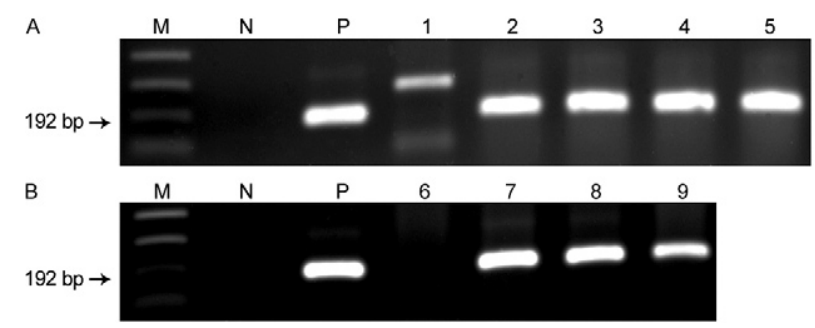

Fig. 3: detection limit of the real-time fluorescence resonance energy transfer polymerase chain reaction for the detection of one, two, four and eight Schistosoma japonicum eggs artificially inoculated into $100 \mathrm{mg}$ non-infected mouse faeces samples (A) and one S. japonicum cercaria artificially inoculated into one, five and 10 Oncomelania nosophora snails (B). Ethidium bromide staining patterns of the amplicon products on a $1.5 \%$ agarose gel. Lane M: DNA size markers (100 bp DNA ladder from Invitrogen); N: [cycle number $(\mathrm{Cn})>40$ ]; P: $(\mathrm{Cn}=21)$, negative and positive control containing distilled water and $S$. japonicum plasmid $1.42 \times 10^{6}$ copies/reaction, respectively; 1 : amplicon product from non-infected mouse faeces $(\mathrm{Cn}>40)$; amplicon products from one $(\mathrm{Cn}=30.03)$ (Lane 2), two $(\mathrm{Cn}=28.30)$ (Lane 3), four $(\mathrm{Cn}=28.13)($ Lane 4$)$ and eight $(\mathrm{Cn}=27.99)($ Lane 5) S. japonicum eggs artificially inoculated into $100 \mathrm{mg}$ non-infected mouse faeces; 6: amplicon products from non-infected $O$. nosophora snails ( $\mathrm{Cn}$ $>40$ ); amplicon products from one S. japonicum cercaria inoculated into aliquots of one $(\mathrm{Cn}=23.64)$ (Lane 7), five $(\mathrm{Cn}=28.0)$ (Lane 8) and $10(\mathrm{Cn}=35.66)($ Lane 9) O. nosophora snails. Arrows indicate the 192 bp $S$. japonicum specific bands. japonicum genomic DNA and the positive control plasmid (Fig. 5, Lanes 1-6, P). However, non-specific bands were also amplified using genomic DNA from some control materials. Although the genomic DNAs from non-infected mouse faeces (Fig. 5, Lane 8), Centrocestus spp (Fig. 5, Lane 10), H. taichui (Fig. 5, Lane 11), F. gigantica (Fig. 5, Lane 12), Stellantchasmus spp (Fig. 5, Lane 16), animal schistosomes (Fig. 5, Lane 17), intestinal lecithodendriid flukes (Fig. 5, Lane 20), S. mekongi (Fig. 5, Lane 24) and $S$. mekongi-infected mouse faeces (Fig. 5, Lane 25) demonstrated various amplified bands, no specific fluorescence signal was detected by the melting curve analysis.

\section{DISCUSSION}

The strategies of transmission control and the interruption of schistosomiasis japonicum require sensitive and specific tests, particularly in areas where the level of endemicity decreases (Lier et al. 2009). Real-time PCR has increasingly superseded c-PCR due to its greatly improved molecular detection efficacy. Not only is this method accurate, rapid and can measure the specific DNA quantity in samples (Lyon \& Wittwer 2009), it also discriminates the species or strains of several pathogenic agents by melting curve analysis. Furthermore, this method offers a high throughput and is performed in a closed system, which eliminates the risk of poten-

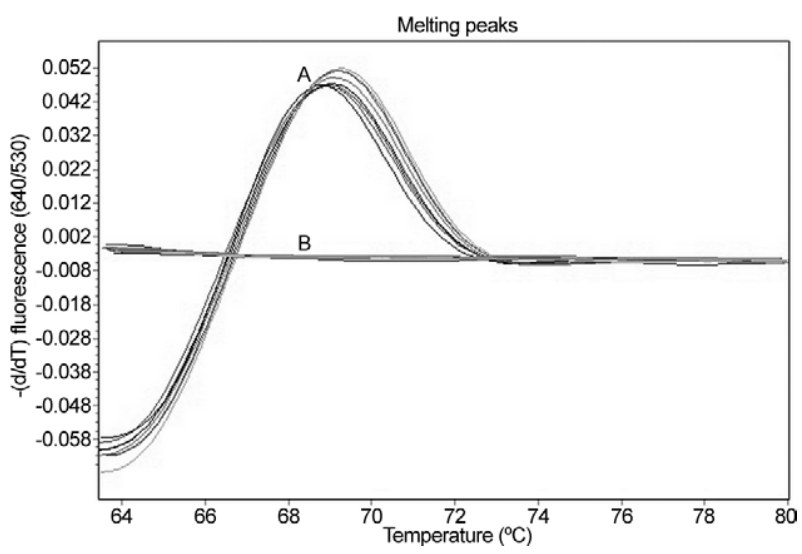

Fig. 4: representative melting curve analysis of two fluorophore-labelled probes hybridized to the amplification products of internal transcribed spacer region 2 DNA from Schistosoma japonicum. The melting temperature (Tm) of the double-stranded fragment is visualized by plotting the negative derivative of the change in fluorescence divided by the change in temperature in relation to the temperature $[-(\mathrm{d} / \mathrm{dT})$ fluorescence (640/530)]. The turning point of this converted melting curve results in a peak and permits easy identification of the fragment specific Tm. Melting curves of positive control plasmid, genomic DNA from $S$. japonicum adults, S. japonicum-infected Oncomelania nosophora snails, $S$. japonicum cercariae and $S$. japonicum-infected mouse faeces (A) as well as genomic DNA from non-infected $O$. nosophora snails, non-infected mouse faeces, Opisthorchis viverrini, Centrocestus spp, Haplorchis taichui, Fasciola gigantica, Echinostoma malayanum, Paragonimus heterotremus, Haplorchoides spp, Stellantchasmus spp, animal schistosomes, Schistosoma mekongi and S. mekongi-infected mouse faeces, human leukocytes, healthy human faeces, individual human faeces infected with Strongyloides stercoralis, Taenia spp, intestinal lecithodendriid flukes and echinostome fluke, respectively and the negative control containing distilled water (B). 
tial cross-over contamination because it does not require agarose gel electrophoresis to visualise the amplicons. The real-time FRET PCR-based method has been successfully used for the detection of several parasites, including Wuchereria bancrofti (Lulitanond et al. 2004), Brugia malayi (Thanchomnang et al. 2008, 2010a), Dirofilaria immitis (Thanchomnang et al. 2010b), Toxoplasma gondii (Brenier-Pinchart et al. 2007), Plasmodium falciparum (Ojurongbe et al. 2007) and $O$. viverrini (Intapan et al. 2008a, b, 2009b).

In this report, we demonstrate that real-time FRET PCR combined with melting curve analysis using two individually labelled hybridisation probes can be used for the sensitive and specific detection of $S$. japonicum infection in snails and faecal samples. This procedure could detect as little as one cercaria implanted in a pool of 10 non-infected $O$. nosophora snails and a single egg inoculated in $100 \mathrm{mg}$ of non-infected mouse faeces. The results were positive in all $S$. japonicum-infected snails and faecal samples from infected mice equalling a $100 \%$ positive rate.

Regarding the analytical specificity of the procedure, no fluorescence was observed despite the amplification of non-specific bands when DNA from some flukes belonging to a different species than $S$. japonicum was tested, indicating a $100 \%$ negative rate. Thus, our real-time

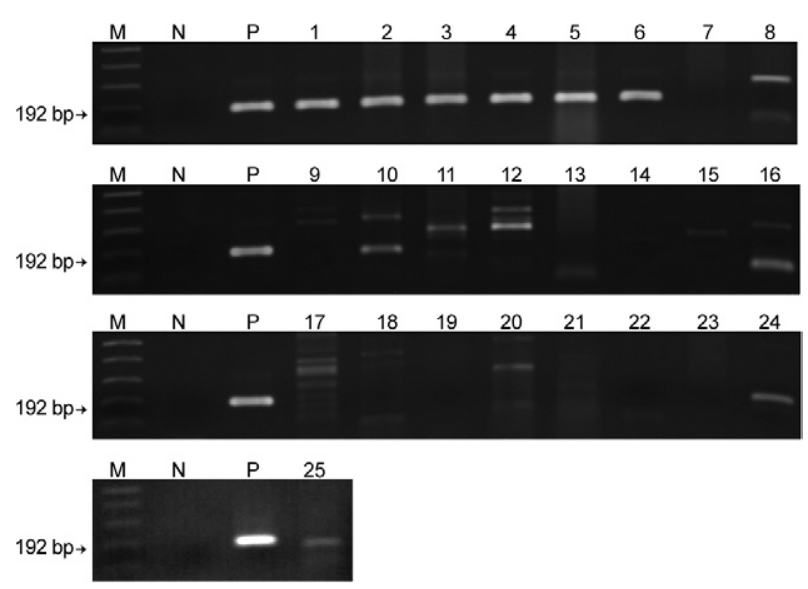

Fig. 5: ethidium bromide staining patterns of the polymerase chain reaction (PCR) products on a $1.5 \%$ agarose gel. The arrows indicate the 192 bp Schistosoma japonicum specific bands. Lanes M: DNA size markers (1 kb plus DNA ladder from Invitrogen); N: negative control containing no DNA; P: the PCR products obtained from the positive control plasmid $1.42 \times 10^{6}$ copies/reaction [cycle number $(\mathrm{Cn})$ $=21.01]$; 1 : genomic DNA (1 ng/reaction) from $S$. japonicum adults $(\mathrm{Cn}=27) ; 2,3: S$. japonicum-infected Oncomelania nosophora snails $(\mathrm{Cn}=9.61-9.65) ; 4$ : five $S$. japonicum cercariae $(\mathrm{Cn}=22.74) ; 5,6: S$. japonicum-infected mouse faeces $(\mathrm{Cn}=22.44-26.48) ; 7$ : non-infected O. nosophora snails; 8: non-infected mouse faeces; 9: Opisthorchis viverrini; 10: Centrocestus spp; 11: Haplorchis taichui; 12: Fasciola gigantica; 13: Echinostoma malayanum; 14: Paragonimus heterotremus; 15: Haplorchoides spp; 16: Stellantchasmus spp; 17: animal schistosomes; individual human faeces infected with 18: Strongyloides stercoralis; 19: Taenia spp; 20: intestinal lecithodendriid flukes; 21: echinostome fluke; 22: human leukocytes; 23: healthy human faeces; 24: Schistosoma mekongi adults; 25: S. mekongi-infected mouse faeces. All $\mathrm{Cn}$ values of negative and other control samples (Lanes N, 7-25) were $>40$.
FRET PCR could be useful for the differentiation of $S$. japonicum cercariae from those of other flukes, such as S. mekongi, O. viverrini, Centrocestus spp, H. taichui, $F$. gigantica, E. malayanum, P. heterotremus, Haplorchoides spp, Stellantchasmus spp and animal schistosomes. This method could also distinguish $S$. japonicum eggs in mouse faecal samples from DNA extracted from human leukocytes, negative human faeces and human faeces infected with $S$. stercoralis, Taenia spp, intestinal lecithodendriid flukes and Echinostoma.

The real-time FRET PCR protocol provides an alternative to the classic or more modern molecular or serological methods for the detection of $S$. japonicum in snails, the first intermediate host and in faecal samples. Because the probes and assay system can be used to detect at least two strains of S. japonicum (Japanese and Philippine strains), this method can provide standardised information about $S$. japonicum epidemiology. The entire protocol (after the extraction of specimen DNA) can be completed within $1 \mathrm{~h}$ and thus is high throughput. A large number of samples can be processed simultaneously, and only small sample volumes are required. This method eliminates the need for laborious, time-consuming microscopic examination by experienced personnel. Moreover, it is independent of the subjective bias that is sometimes present in microscopic examinations and avoids confusion with other miscellaneous parasite eggs. Nevertheless, no significant correlation between $\mathrm{Cn}$ and the $S$. japonicum egg amount in the faecal samples was observed. This may be due to miracidium DNA degradation in S. japonicum eggs in the faecal samples. Further studies are needed to improve the quantitative efficacy of this method.

In conclusion, a specific, sensitive and fast real-time FRET PCR for the detection of S. japonicum in snail intermediate hosts and in infected mouse faecal samples is reported here. This test is suitable for not only epidemiological studies and eradication programs for intermediate hosts, but also for the possible diagnosis of human infection in Asian populations.

\section{ACKNOWLEDGEMENTS}

To Dr Yukifumi Nawa, for comments and suggestions, and to Dr Mark Roselieb, for his assistance in preparing the paper.

\section{REFERENCES}

Bowles J, Blair D, McManus DP 1995. A molecular phylogeny of the human schistosomes. Mol Phylogenet Evol 4: 103-109.

Brenier-Pinchart MP, Morand-Bui V, Fricker-Hidalgo H, Equy V, Marlu R, Pelloux H 2007. Adapting a conventional PCR assay for Toxoplasma gondii detection to real-time quantitative PCR including a competitive internal control. Parasite14: 149-154.

Doenhoff MJ, Chiodini PL, Hamilton JV 2004. Specific and sensitive diagnosis of schistosome infection: can it be done with antibodies? Trends Parasitol 20: 35-39.

Gryseels B, Polman K, Clerinx J, Kestens L 2006. Human schistosomiasis. Lancet 368: 1106-1118.

Hung YW, Remais J 2008. Quantitative detection of Schistosoma japonicum cercariae in water by real-time PCR. PLoS Negl Trop Dis 2: e337. 
Intapan PM, Thanchomnang T, Lulitanond V, Maleewong W 2009a. Rapid detection of Wuchereria bancrofti and Brugia malayi in mosquito vectors (Diptera: Culicidae) using a real-time fluorescence resonance energy transfer multiplex PCR and melting curve analysis. J Med Entomol 46: 158-164.

Intapan PM, Thanchomnang T, Lulitanond V, Phongsaskulchoti P, Maleewong W 2008a. Real-time fluorescence resonance energy transfer PCR with melting curve analysis for the detection of Opisthorchis viverrini in fish intermediate hosts. Vet Parasitol 157: 65-71.

Intapan PM, Thanchomnang T, Lulitanond V, Pongsaskulchoti P, Maleewong W 2008b. Detection of Opisthorchis viverrini in infected bithynid snails by real-time fluorescence resonance energy transfer PCR-based method and melting curve analysis. Parasitol Res 103: 649-655.

Intapan PM, Thanchomnang T, Lulitanond V, Pongsaskulchoti P, Maleewong W 2009b. Rapid molecular detection of Opisthorchis viverrini in human fecal samples by real-time polymerase chain reaction. Am J Trop Med Hyg 81: 917-920.

Kato-Hayashi N, Kirinoki M, Iwamura Y, Kanazawa T, Kitikoon V, Matsuda H, Chigusa Y 2010. Identification and differentiation of human schistosomes by polymerase chain reaction. Exp Parasitol 124: 325-329.

King CH, Dickman K, Tisch DJ 2005. Reassessment of the cost of chronic helminthic infection: a meta-analysis of disability-related outcomes in endemic schistosomiasis. Lancet 365: 1561-1569.

Lier T, Johansen MV, Hjelmevoll SO, Vennervald BJ, Simonsen GS 2008. Real-time PCR for detection of low intensity Schistosoma japonicum infections in a pig model. Acta Trop 105: 74-80.

Lier T, Simonsen GS, Haaheim H, Hjelmevoll SO, Vennervald BJ, Johansen MV 2006. Novel real-time PCR for detection of Schistosoma japonicum in stool. Southeast Asian J Trop Med Public Health 37: 257-264.

Lier T, Simonsen GS, Wang T, Lu D, Haukland HH, Vennervald BJ, Hegstad J, Johansen MV 2009. Real-time polymerase chain reaction for detection of low-intensity Schistosoma japonicum infections in China. Am J Trop Med Hyg 81: 428-432.

Lulitanond V, Intapan PM, Pipitgool V, Choochote W, Maleewong W 2004. Rapid detection of Wuchereria bancrofti in mosquitoes by LightCycler polymerase chain reaction and melting curve analysis. Parasitol Res 94: 337-341.
Lyon E, Wittwer CT 2009. LightCycler technology in molecular diagnostics. J Mol Diagn 11: 93-101.

Ojurongbe O, Ogungbamigbe TO, Fagbenro-Beyioku AF, Fendel R, Kremsner PG, Kun JF 2007. Rapid detection of Pfcrt and Pfmdr1 mutations in Plasmodium falciparum isolates by FRET and in vivo response to chloroquine among children from Osogbo, $\mathrm{Ni}$ geria. Malar J 6: 41.

Qiu DC, Hubbard AE, Zhong B, Zhang Y, Spear RC 2005. A matched, case-control study of the association between Schistosoma japonicum and liver and colon cancers in rural China. Ann Trop Med Parasitol 99: 47-52.

Thanchomnang T, Intapan PM, Chungpivat S, Lulitanond V, Maleewong W 2010a. Differential detection of Brugia malayi and Brugia pahangi by real-time fluorescence resonance energy transfer PCR and its evaluation for diagnosis of $B$. pahangi-infected dogs. Parasitol Res 106: 621-625.

Thanchomnang T, Intapan PM, Lulitanond V, Choochote W, Manjai A, Prasongdee TK, Maleewong W 2008. Rapid detection of Brugia malayi in mosquito vectors using a real-time fluorescence resonance energy transfer PCR and melting curve analysis. Am J Trop Med Hyg 78: 509-513.

Thanchomnang T, Intapan PM, Lulitanond V, Sangmaneedet S, Chungpivat S, Taweethavonsawat P, Choochote W, Maleewong W 2010b. Rapid detection of Dirofilaria immitis in mosquito vectors and dogs using a real-time fluorescence resonance energy transfer PCR and melting curve analysis. Vet Parasitol 168: 255-260.

Xia CM, Rong R, Lu ZX, Shi CJ, Xu J, Zhang HQ, Gong W, Luo W 2009. Schistosoma japonicum: a PCR assay for the early detection and evaluation of treatment in a rabbit model. Exp Parasitol 121: $175-179$.

Xu J, Rong R, Zhang HQ, Shi CJ, Zhu XQ, Xia CM 2010. Sensitive and rapid detection of Schistosoma japonicum DNA by loop-mediated isothermal amplification (LAMP). Int J Parasitol 40: 327-331.

Zhou XN, Bergquist R, Leonardo L, Yang GJ, Yang K, Sudomo M, Olveda R 2010. Schistosomiasis japonica control and research needs. Adv Parasitol 72: 145-178.

Zhou XN, Guo JG, Wu XH, Jiang QW, Zheng J, Dang H, Wang XH, Xu J, Zhu HQ, Wu GL, Li YS, Xu XJ, Chen HG, Wang TP, Zhu YC, Qiu DC, Dong XQ, Zhao GM, Zhang SJ, Zhao NQ, Xia G, Wang LY, Zhang SQ, Lin DD, Chen MG, Hao Y 2007. Epidemiology of schistosomiasis in the People's Republic of China, 2004. Emerg Infect Dis 13: 1470-1476. 